\title{
Evaluation of potential of fruit weight and fruit width and their interrelationships in the set of apricot genotypes
}

\author{
Vachùn, Z. \\ Mendel University of Agriculture and Forestry \\ Faculty of Horticulture, Department of Fruit Growing and Viticulture \\ 69144 Lednice,Czech Republic,e-mail:vachun@mendelu.hu
}

Summary: Within the period of 1994-1999, variability of fruit weight and width was evaluated in altogether 24 apricot genotypes. It is concluded that the genotype and climatic conditions of individual years are the factors causing variability in these two parameters of apricot fruits. Variability of fruit weight was significantly higher (approximately 3-times) than that of fruit width. When evaluated on the base of their width, $75.0 \%$ and $95.8 \%$ of apricots were classified into the groups of extra and first quality, respectively. As genotypes with the maximum fruit width (i. e. above $50 \mathrm{~mm}$ ) the following cultivars were classified: 'Velkopavlovická LE-6/2', 'NJA-1', 'M 45', 'M-25' and Lednická (M-90-A)'. The value of fruit width (in $\mathrm{mm}$ ) corresponded with its weight (in $\mathrm{g}$ ) only within the range of $40-45 \mathrm{~mm}$. With the increasing and/or decreasing size of apricot fruit the changes in fruit weight were more pronounced than in those in fruit width. Within the set of genotypes under study, this relationship may be expressed by the equation $y=0.1234-7.6605+152.76$; the corresponding values of correlation coefficient and coefficient of curve determination are $r=0.95++$ and $R 2=0.959$.

Key words: apricot, genotypes, fruit weight, fruit width

\section{Introduction}

In apricots, both the weight and the width of fruit represent important not only morphological but also qualitative traits. According to present standards, the size of fruit is the parameter that is used for their classification into individual quality categories. Quantitatively this trait is expressed by the width of fruit. Weight of apricots, their width and some other parameters are traits that are mentioned as basic characteristics of individual varieties not only in every more detailed textbook of pomology (Della Strada, Pennone, Fidighelli et al., 1989; Kutina, Barborka, Cvopa et al., 1991) but also in many scientific publications (Mitreski, 1990; Badenas, Llacer, Asins, 1993). Only few authors analysed variability of these traits and evaluated their interrelationships in larger sets of genotypes and under conditions of different years (Akca, Sen, 1995; Okut, Akca, 1995). Some authors used selected quantitative traits of fruit in studies on genetic resources (Paunovič, Paunovič, 1993; Akca, Sen,1995; Akca, Sen, Karayannis, 1999; Zhang-LiBin, Liu-Guei, 1997; Onal, 1999). Data about weight and other parameters of fruit are used when pre-selecting new genotypes within the framework of breeding programmes (Vachuin, Krška, Sasková et al., 1996)

\section{Material and method}

Experimental apricot plantation was established in the spring of 1991. Each genotype was represented by five trees. Grafts used for the preparation of this collection originated from the Czech Republic, Slovak Republic, Ukraine, Canada and USA. Altogether only 24 genotypes were selected for the final evaluation from a wider collection of cultivars. Within the period of six years (1994-1999) only this ones had complete examination dates. Genotypes with letters LE and $\mathrm{M}$ were hybrids originating from the selection programme of the Faculty of Horticulture in Lednice (Mendel University of Agriculture Brno). All were pre-selected as prospective hybrid combinations in experimental orchards and propagated for the so-called station test. The most important ones (at present already registered as new cultivars) are mentioned in this paper under their new variety names. However, their original working names are presented in parentheses with letters LE), for example the variety Lemeda (LE-962)'. The variety 'Velkopavlovická' (clone LE-6/2) was used as control. Apricot seedlings were used as rootstocks in all cases. Soil type was classified as a sandyloamy alluvial soil. The same farming measures and the same method of pruning were used in all variants and no thinning of fruit was performed during the whole experiment. Within the experimental period (1994-1999), the mean annual temperature in Lednice was $9.8^{\circ} \mathrm{C}$; this temperature was by $0.8^{\circ} \mathrm{C}$ higher than the eighty-year average. The mean annual sum of precipitation was $526 \mathrm{~mm}$ and corresponded with the long-term average. In individual years of the study period, however, these annual sums were very different and ranged from $480 \mathrm{~mm}$ to $626 \mathrm{~mm}$. This means that the studyeriod was generally warmer and with marked differences in annual precipitation. Years 1995 and 1996 were for apricots favourable and the year 1999 even very favourable. In the remaining three years $(1994,1997$ and 1998) the climatic 
conditions were less favourable, partly due to the occurrence of late frosts in the period of flowering and partly due to rainy weather that impaired pollination.

Fruit characteristics were evaluated according to a modified methodology described by Vachün, \& Krška(1991) \& Vachuin, Krška, Sasková et al. (1995). A classificator for apricots (Nitransk", 1992) was used as well. In 1994-1999, five apricot fruits were randomly sampled from each tree for this evaluation so that their total number was 25 per each genotype. Exceptionally this number was lower due to the loss of some trees. Always, however, the number of apricots was not lower than 15 because individual sampling involved least three trees. For the estimation of weight, width, height and thickness, an average fruit was taken from each sample.

The weight of fruit was estimated in grams and the width was measured in millimetres. Both values were estimated on the same apricot fruit. The fruit width was measured as the dorsiventral distance (in $\mathrm{mm}$ ) between the ridge of fruit and its groove. Instead of fruit width, some authors also used the term "diagonal diameter." This definition was used for instance in the Czech standard (,,idt UN/ECE FFV02 for apricots") that has been already harmonised with EU standards. In this standard, the value of this diagonal diameter is used as the basic criterion of classification of apricots into individual quality groups (categories).

The standard deviation ( $\mathrm{sx}$ ) was used for characterisation of accumulation of values around the arithmetic mean. The comparison of genotypes was based on the presumption that the range of $2 \mathrm{sx}$ involved $95 \%$ of all values measured for each genotype within a six-year period.

\section{Results and discussion}

The average weight of apricots, as estimated within a sixyear period in a set of 24 apricot genotypes, was $44 \mathrm{~g}$ and ranged from $28 \mathrm{~g}$ ('LE-SEO-24) to $78 \mathrm{~g}$ ('NJA-1'). The weight of fruit was significantly affected by the year of harvest. The average weight of the whole set ranged from 32 $\mathrm{g}$ to $58 \mathrm{~g}$ in individual years of the period 1994-1999 (Table 1). As expected, the lowest average size of fruit was recorded in years of the highest harvests.

Different genetic ground and significantly different meteorological conditions were the main factors influencing the capability of individual genotypes to produce without thinning apricots of greater or smaller width and weight. In years with low harvests the weight and size of fruit of individual genotypes were near the upper limits of all genotypes, i. e. near the maximum possible values of both traits under study The maximum and minimum values of fruit width are presented in Fig. 1 .

There were highly significant or significant correlations among the ranks of fruit weight in individual years of our study period (ranging from $r=0.44+$ to $r=0.85++$ ). Similar correlations were recorded also in fruit width (Tables 2 and 3). This indicates that the size of fruit is a variety-typical characteristic. Year pairs 1994-1999 and 1998-1999 were the only exceptions from this rule, probably due to the fact that in these years there were extreme differences in fruit harvests. In years 1994 through 1998, the average harvests of fruit per tree were as follows: $0.84 \mathrm{~kg} ; 9.51 \mathrm{~kg} ; 8.86 \mathrm{~kg}$; $3.41 \mathrm{~kg}$ and $35.47 \mathrm{~kg}$, respectively.

Table 1 Fruit weights of apricot genotypes and their standard deviations within the period of 1994-1999

\begin{tabular}{|c|c|c|c|c|c|c|c|c|}
\hline \multirow{2}{*}{ Genotype } & \multicolumn{6}{|c|}{ Year } & \multirow{2}{*}{ Mean } & \multirow{2}{*}{$\begin{array}{c}\text { Standard } \\
\text { deviation (sx }\end{array}$} \\
\hline & 1994 & 1995 & 1996 & 1997 & 1998 & 1999 & & \\
\hline HARLAYNE & 37.00 & 34.70 & 26.20 & 35.36 & 47.50 & 36.00 & 36.13 & 6.21 \\
\hline LE-392 & 34.20 & 41.98 & 21.20 & 36.93 & 41.00 & 28.00 & 33.88 & 7.31 \\
\hline PRIUSADEBNYI & 46.20 & 24.40 & 16.40 & 31.80 & 41.12 & 21.20 & 30.19 & 10.67 \\
\hline SEM.BADEMERIK & 41.00 & 41.95 & 22.00 & 47.85 & 50.00 & 30.00 & 38.80 & 9.85 \\
\hline LE-2267 & 47.40 & 55.70 & 40.40 & 52.74 & 69.00 & 34.00 & 49.87 & 11.22 \\
\hline LE-390 & 64.80 & 37.34 & 39.20 & 46.84 & 61.00 & 22.00 & 45.20 & 14.56 \\
\hline LE-1917 & 52.00 & 48.50 & 25.00 & 50.80 & 41.00 & 45.00 & 43.72 & 9.14 \\
\hline NJA-1 & 90.00 & 81.24 & 60.20 & 79.30 & 121.00 & 40.00 & 78.62 & 25.05 \\
\hline ARZAMI AROMATNYI & 48.60 & 29.03 & 30.60 & 33.08 & 72.00 & 23.50 & 39.47 & 16.46 \\
\hline VOLEBNYI & 59.80 & 41.90 & 41.20 & 49.60 & 50.00 & 34.00 & 46.08 & 8.20 \\
\hline VYNOSLIVYI & 49.50 & 31.66 & 46.40 & 35.00 & 41.60 & 47.00 & 41.86 & 6.54 \\
\hline M-45 & 68.25 & 57.46 & 39.80 & 64.90 & 58.00 & 54.00 & 57.07 & 9.08 \\
\hline M-25 & 49.33 & 47.15 & 40.80 & 46.75 & 67.00 & 53.00 & 50.67 & 8.16 \\
\hline VELKOPAVLOVICKÁ LE-6/2 & 56.67 & 53.42 & 37.20 & 47.00 & 82.00 & 58.00 & 55.71 & 13.67 \\
\hline HAROGEM & 48.20 & 32.10 & 37.60 & 50.46 & 60.00 & 24.00 & 42.06 & 12.08 \\
\hline LE-2185 & 33.00 & 29.50 & 31.00 & 35.23 & 37.00 & 30.00 & 32.62 & 2.75 \\
\hline LE-1580 & 47.50 & 49.58 & 28.20 & 48.97 & 52.00 & 52.00 & 46.37 & 8.29 \\
\hline SABINOVSKA 220 & 50.50 & 37.94 & 25.60 & 44.40 & 46.00 & 52.00 & 42.74 & 8.91 \\
\hline LE-1453 & 51.40 & 38.48 & 28.40 & 37.92 & 70.00 & 29.00 & 42.53 & 14.45 \\
\hline LEMEDA (LE-962) & 48.00 & 50.60 & 23.60 & 40.20 & 52.20 & 29.00 & 40.60 & 10.90 \\
\hline LE-1321 & 45.60 & 46.90 & 29.80 & 42.54 & 62.00 & 29.00 & 42.64 & 11.20 \\
\hline LEDNICKÁ (M-90-A) & 54.50 & 55.00 & 44.70 & 50.16 & 58.00 & 53.00 & 52.56 & 4.22 \\
\hline LE-SEO-118 & 47.40 & 45.85 & 18.50 & 48.10 & 60.00 & 29.00 & 41.48 & 13.69 \\
\hline LE-SEO-24 & 36.40 & 35.50 & 12.00 & 28.35 & 42.00 & 16.00 & 28.38 & 10.97 \\
\hline Mean & 50.30 & 43.66 & 31.92 & 45.18 & 57.56 & 36.20 & 44.14 & 10.57 \\
\hline
\end{tabular}




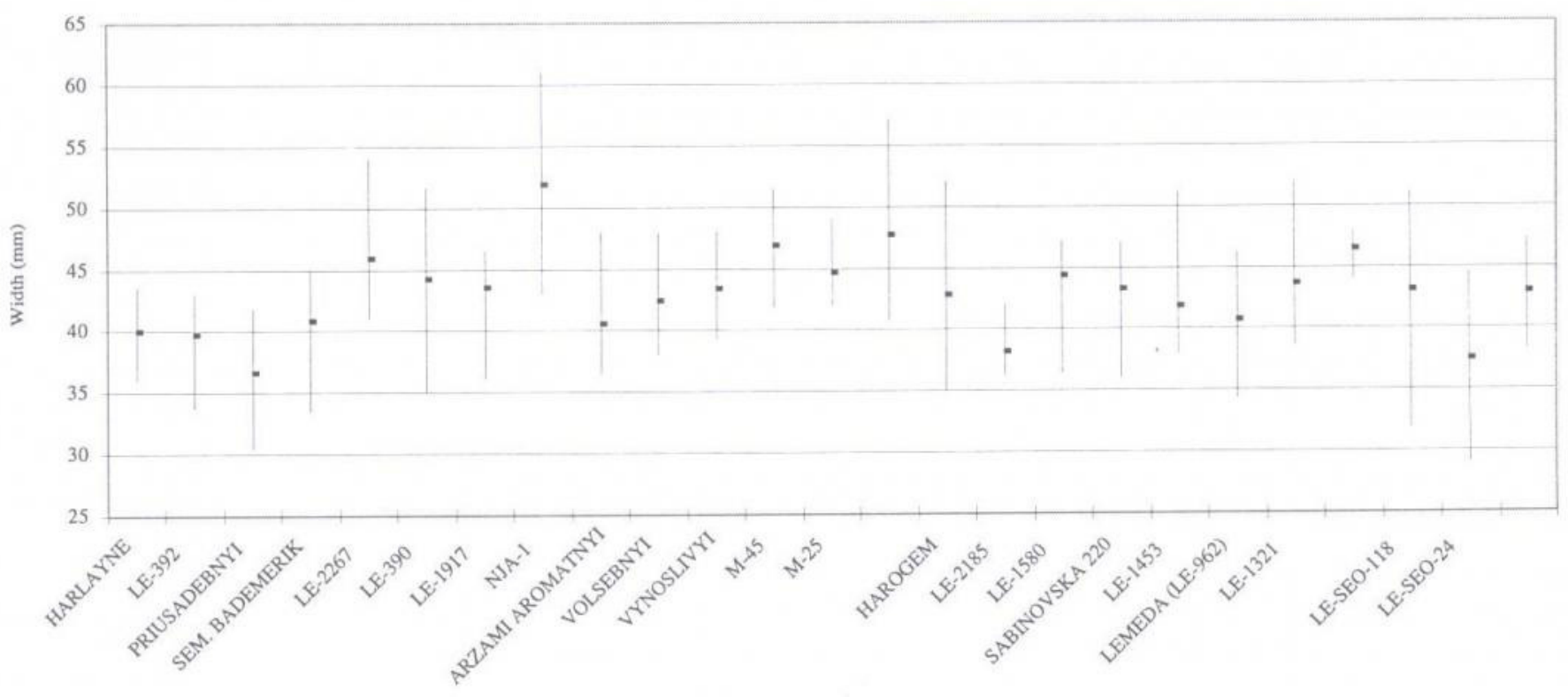

Ge notypes

Maximum Minimum - Mean

Figure I Maximum, minimum and mean fruit width ok apricot genotypes within a six-year period

Table 2 Fruit widhts of apricot geneotypes and their standard deviations from the mean within the period of 1994-1999

\begin{tabular}{|c|c|c|c|c|c|c|c|c|}
\hline \multirow{2}{*}{ Genotype } & \multicolumn{6}{|c|}{ Year } & \multirow{2}{*}{ Mean } & \multirow{2}{*}{$\begin{array}{c}\text { Standard } \\
\text { deviation (sx) }\end{array}$} \\
\hline & 1994 & 1995 & 1996 & 1997 & 1998 & 1999 & & \\
\hline HARLAYNE & 41.40 & 40.00 & 36.00 & 39.00 & 43.50 & 40.00 & 39.98 & 2.28 \\
\hline LE-392 & 40.80 & 42.00 & 33.80 & 39.80 & 43.00 & 39.00 & 39.73 & 2.96 \\
\hline PRIUSADEBNYI & 41.80 & 35.40 & 30.40 & 35.80 & 41.40 & 35.20 & 36.67 & 3.93 \\
\hline SEM.BADEMERIK & 42.00 & 42.80 & 33.50 & 43.30 & 45.00 & 39.00 & 40.93 & 3.78 \\
\hline LE-2267 & 45.80 & 46.80 & 43.00 & 45.20 & 54.00 & 41.00 & 45.97 & 4.0 \\
\hline LE-390 & 51.60 & 41.80 & 42.00 & 44.20 & 50.00 & 35.00 & 44.17 & 5.51 \\
\hline LE-1917 & 46.00 & 46.40 & 36.20 & 45.50 & 42.00 & 45.00 & 43.52 & 3.57 \\
\hline NJA-1 & 54.80 & 51.80 & 49.40 & 51.00 & 61.00 & 43.00 & 51.83 & 5.4 \\
\hline ARZAMI AROMATNYI & 45.20 & 37.80 & 37.40 & 38.60 & 48.00 & 36.50 & 40.58 & 4.37 \\
\hline VOLEBNYI & 47.80 & 41.20 & 41.00 & 42.50 & 44.00 & 38.00 & 42.42 & 3.01 \\
\hline VYNOSLIVYI & 48.00 & 40.20 & 44.20 & 39.40 & 43.60 & 45.00 & 43.40 & 2.91 \\
\hline M-45 & 51.50 & 47.00 & 41.80 & 48.00 & 46.00 & 47.00 & 46.88 & 2.8 \\
\hline M-25 & 44.00 & 43.80 & 42.00 & 43.30 & 49.00 & 46.00 & 44.68 & 2.26 \\
\hline VELKOPAVLOVICKÁ LE-6/2 & 47.00 & 46.80 & 40.80 & 44.30 & 57.00 & 50.00 & 47.65 & 5.04 \\
\hline HAROGEM & 45.20 & 38.80 & 41.80 & 44.60 & 52.00 & 35.00 & 42.90 & 5.35 \\
\hline LE-2185 & 37.60 & 36.30 & 37.50 & 39.30 & 42.00 & 37.00 & 38.28 & 1.89 \\
\hline LE-1580 & 44.00 & 47.20 & 36.40 & 44.30 & 47.00 & 47.00 & 44.32 & 3.77 \\
\hline SABINOVSKA 220 & 46.50 & 42.20 & 36.00 & 43.00 & 45.00 & 47.00 & 43.28 & 3.68 \\
\hline LE-1453 & 45.00 & 39.40 & 38.003 & 39.80 & 51.00 & 38.00 & 41.87 & 4.72 \\
\hline LEMEDA (LE-962) & 43.20 & 43.60 & 34.40 & 40.30 & 46.20 & 37.00 & 40.78 & 4.05 \\
\hline LE-1321 & 45.20 & 45.00 & 38.60 & 42.20 & 52.00 & 39.00 & 43.67 & 4.53 \\
\hline LEDNICKÁ (M-90-A) & 47.60 & 47.20 & 44.00 & 44.80 & 47.00 & 48.00 & 46.43 & 1.49 \\
\hline LE-SEO-118 & 46.00 & 46.00 & 31.80 & 45.00 & 51.00 & 39.00 & 43.13 & 6.16 \\
\hline LE-SEO-24 & 40.80 & 40.80 & 29.00 & 38.00 & 44.50 & 32.00 & 37.52 & 5.38 \\
\hline Mean & 45.37 & 42.93 & 38.31 & 42.55 & 47.72 & 40.78 & 42.94 & 3.03 \\
\hline
\end{tabular}



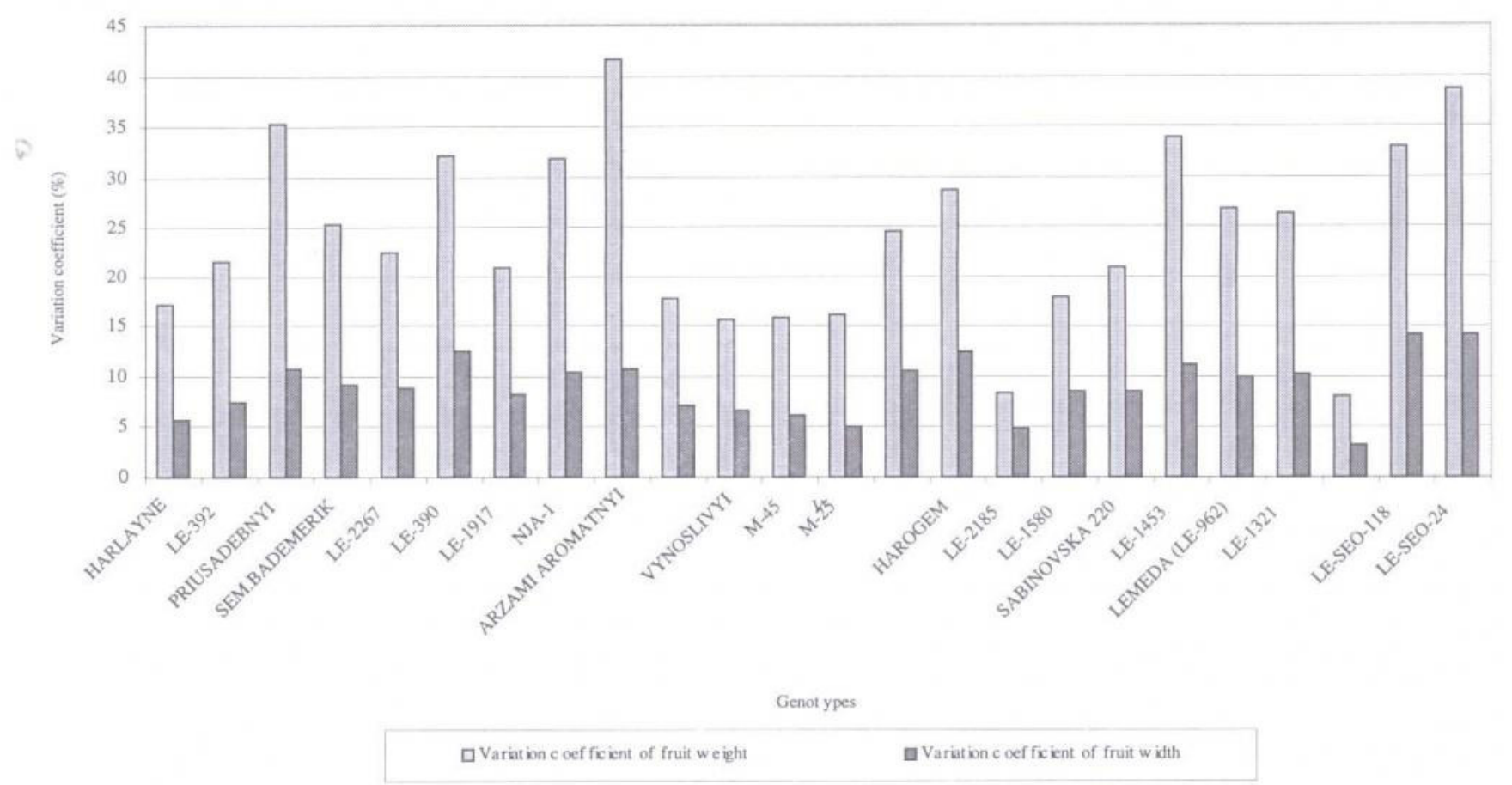

Figure 2 Variation coefficients of fruit weight and width in 24 apricot genotypeswithin the six-year period of 1994-1999

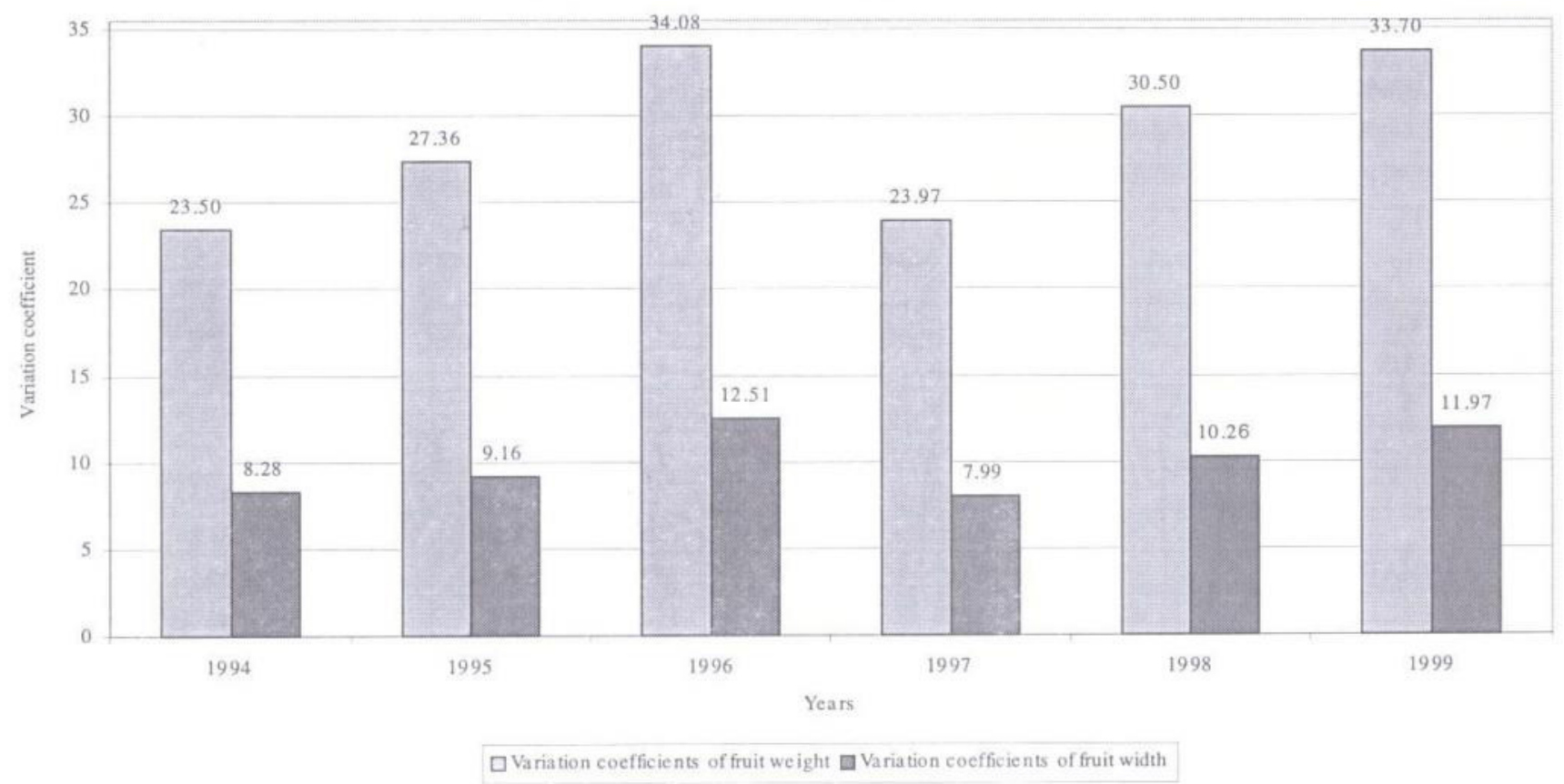

Figure 3 Variation coefficiens of fruit weight and within the whole set of apricot genotypes in individual years of the period 1994-1999

Regardless to different harvests in individual years, the width of fruit of all genotypes was in all years greater than $30 \mathrm{~mm}$. This enabled (with regard to all other criteria of selection) to classify apricots practically in all genotypes and all years (with the exception of 'LE-SEO-24") as at least the 1st quality fruit (according to the Czech standard ÈSN as harmonised with standards of European Union). With the exception of six genotypes (i. .e. 'Priusadebnyi', 'Sem.
Badem Erik', 'LE-392', 'Lemeda', 'LE-SEO-118' and 'LESEO-24') it was possible to classify harvested fruit also into the extra quality group in all years under study. Within a sixyear period, the average width of fruit was greater than 35 $\mathrm{mm}$ in all other genotypes (Table2, Fig. I).

Within the six-year experimental period, the variability of fruit weight was significantly higher than that of fruit width. This was documented by values of coefficients of 
Table 3 Correlations between the rank of fruit width o apricot genotypes in individual pairs of years within the period of 1994-1999

\begin{tabular}{|c|c|c|c|c|c|c|}
\hline Year & 1994 & 1995 & 1996 & 1997 & 1998 & 1999 \\
\hline 1994 & 1 & & & & & \\
\hline 1995 & $0,59^{* *}$ & 1 & & & & \\
\hline 1996 & $0,72^{* *}$ & $0,43^{*}$ & 1 & & & \\
\hline 1997 & $0,73^{* *}$ & $0,84^{* *}$ & $0,62^{* *}$ & 1 & & \\
\hline 1998 & $0,57^{* *}$ & $0,56^{* *}$ & $0,56^{* *}$ & $0,61^{* *}$ & 1 & \\
\hline 1999 & 0.38 & $0,62^{* *}$ & $0,44^{*}$ & $0,52^{* *}$ & 0.18 & 1 \\
\hline
\end{tabular}

** Higly significant correlation

* Significant correlation variation of both fruit weight and fruit size that ranged from $\mathrm{v}=8.04 \%$ to $41.70 \%$ and from $\mathrm{v}=3.21^{\circ} \%$ to $\mathrm{v}=14.33^{\circ} \%$, respectively. (Fig. 2).

As compared with values of fruit width, variation coefficients of fruit weight were higher in all genotypes in individual years of the study period. Coefficients of variation of fruit weight and fruit width ranged from $\mathrm{v}=$ $23.50 \%$ to $\mathrm{v}=34.08 \%$ and from $\mathrm{v}=7.99^{\circ} \%$ to $\mathrm{v}=12.51 \%$, respectively. (Fig. 3). These relationships were corroborated

within the period of 6 years

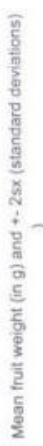

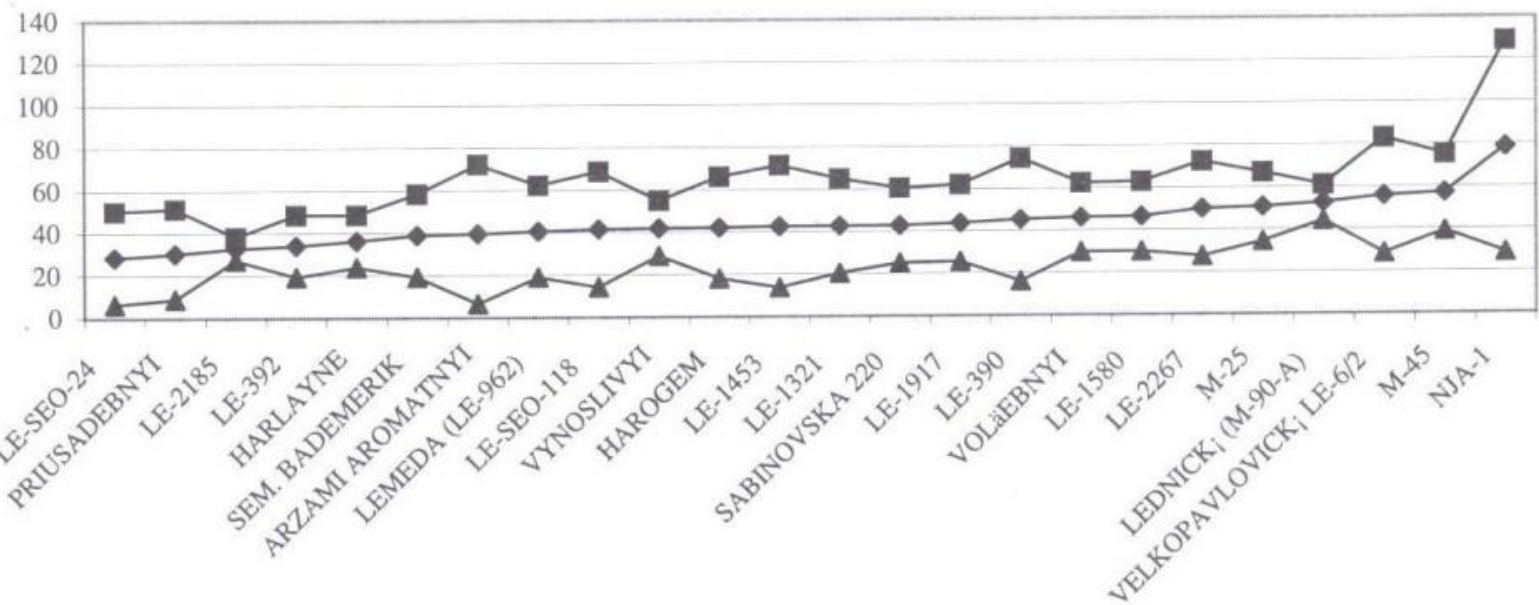

Genotypes

$\longrightarrow$ Mean fruit weight $-\mathbf{a}-+2 \mathrm{sx} \longrightarrow-2 \mathrm{sx}$

Figure 4 Variations of standard deviations $(+2 s x)$ of fruit weights of apricot genotypes within the period of 6 years

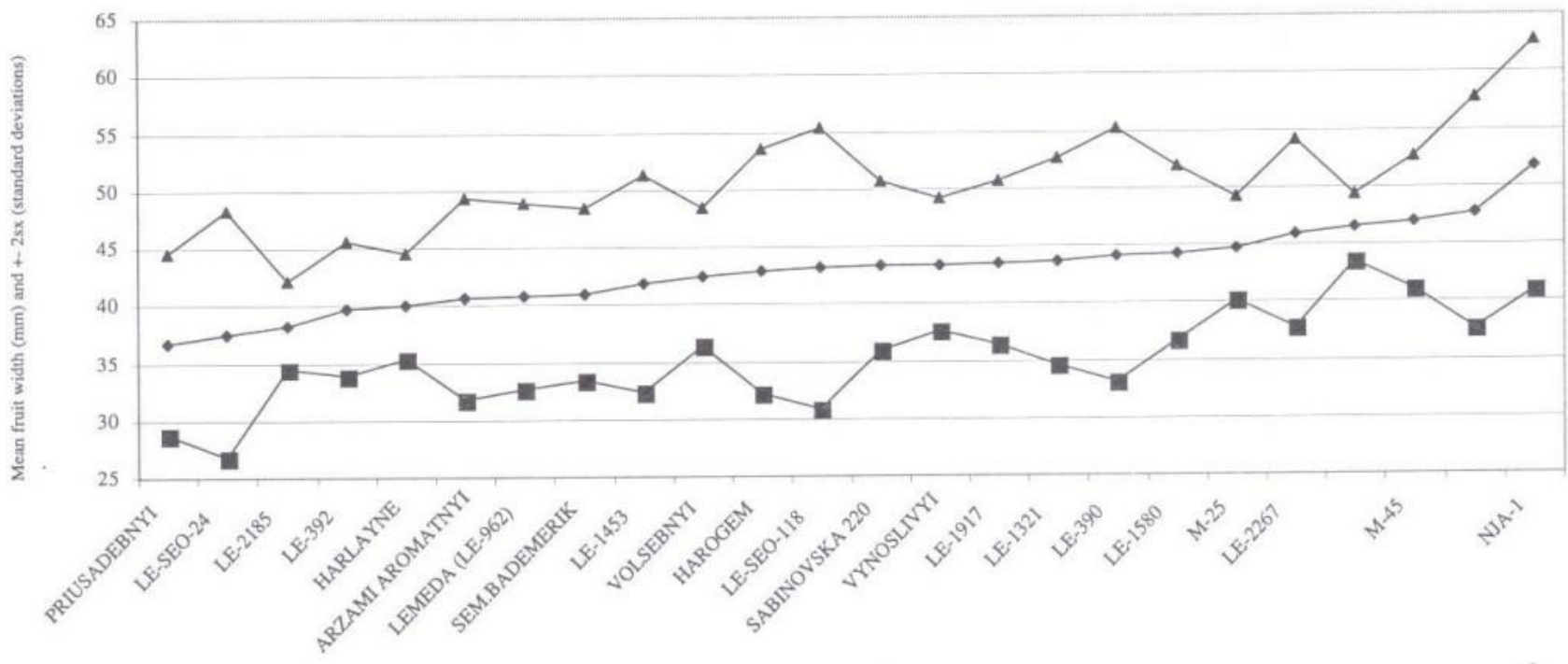

Ge notypes

$\rightarrow-$ Mean fruit width $\rightarrow+25 x--25 x$

Figure 5 Variations of standard dviations $(+2 \mathrm{sx})$ of fruit of apricot genotypes with the period of 6 years 
also by the accumulation of recorded values around the arithmetic mean as expressed on the base of standard deviations for fruit weight (Fig. 4) and fruit width (Fig. 5). As compared with the fruit width, a greater variability and greater differences of recorded values of fruit weight from the mean can be explained by the fact that this trait is influenced by more factors (e. g. greater or smaller free space around fruit stone, greater or smaller seed inside the stone etc.) than the fruit width.
In the set of genotypes under study, the fruit weight corresponded to its width only within the range of 40 to 45 $\mathrm{mm}$. Higher values of fruit width were correlated with increasing weights. On the other hand, the decreasing size of apricots was associated with a more rapid reduction of weight as related to fruit width. This can be explained by the fact that in smaller apricots the reduction of their pulp (mesocarp) is more pronounced than that of fruit stone while in greater ones the increase in pulp (mesocarp) proportion is more rapid than

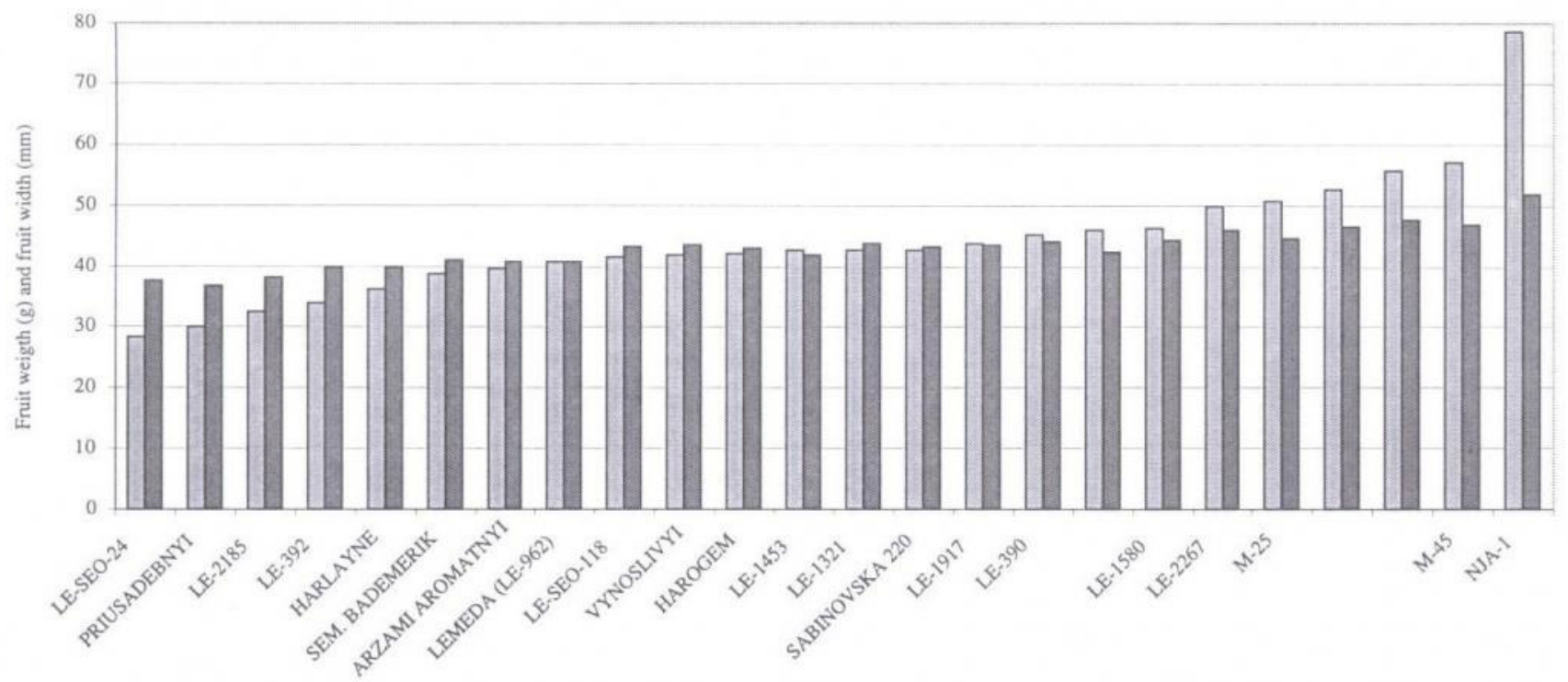

Ge notypes

$\square \mathrm{M}$ an fruit weight $\mathbf{M k}$ an fruit width

Figure 6 Average fruit weight and width in 24 apricot genotypes

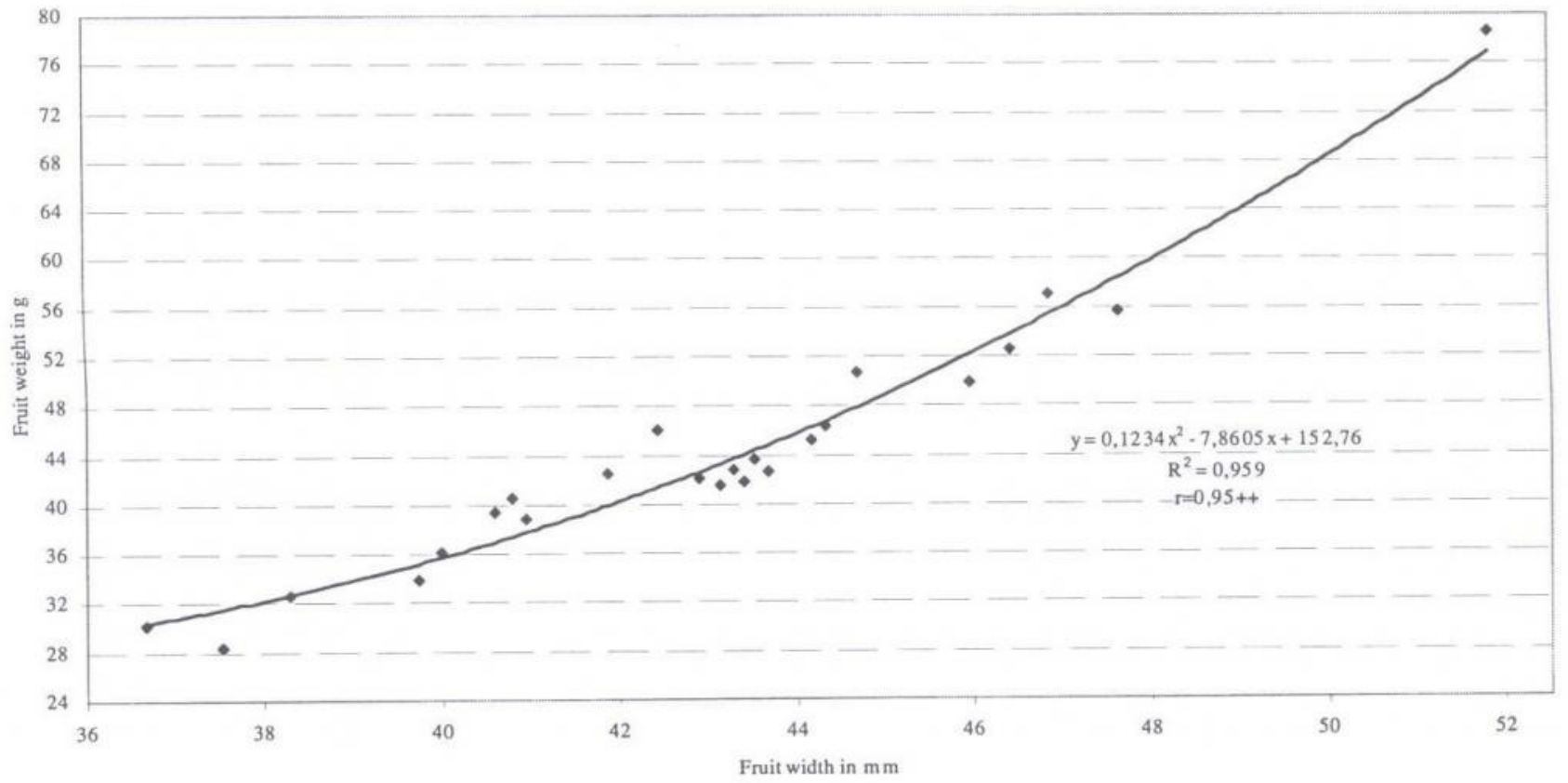

Figure 7 Relationship between average fruit width and weight within the whole set 24 apricot in individual years of the period 1994-1999 
that of fruit stone. This means that in bigger apricots the proportion of edible parts of fruit is greater (Fig. 6).

In the set of genotypes under study, the relationship existing between the mean fruit width and weight may be expressed by the equation $y=0.1234-7.6605+152.76$; the corresponding values of correlation coefficient and coefficient of curve determination are $r=0.95++$ and $R 2=$ 0.959 (Fig. 7).

\section{References}

Akca, Y. \& Sen, S. M. (1995): Repeatability in the Prunus armeniaca L. and the Importance of Repeatability in Breeding Selection. Acta Hort., 384: 215-218

Akca, Y., Sen, S. M. \& Karayannis, I. (1999): Studies on Selection of Apricots with good Quality and Resistance to late Spring Frosts in Gevas Plain. Acta Hort., 488: 135-137

Badenas, M. L., Llacer, G, \& Asisns, M. J. et al. (1993): Pomological Characterization of Apricot Varieties and Clones. Investigatio Agraria, Production y protection vegetales, 8:1, 55-65. Della Strada, G., Pennone, F. \& Fidighellei, C. et al. (1989): Monografia di cultivar di Albicocco, Roma

Kutina, J., Barborka, A. \& Cvopa, J. et al. (1991): Pomologick atlas 1 , Zemědělské nakladatelství, Praha

Mitreski, Z. (1990): Studies on the most important Fruit Properties of some American Cultivars in the Skopje Region. Godisen zbornik na Zemledelskiot Fakultet na Univerzitetot vo Skopje, 37: 73-80. Nitranský, Ś (1992): Klasifikátor - Descriptor List Genus Armeniaca P. Mill. Praha

Okut, H. \& Akca, Y. (1995): Study to Determine the causal Relations between Fruit Weight and certain important Fruit Characteristics with Using a path Analysis, Acta Hort., 384: 97-102, 384: 215-218.

Onal, K. (1999): Evaluation of Apricot (Prunus armeniaca L.) genetic Resources collected from Southeast Anatolia Region, Turkish Journal of Agriculture and Forestry, 23: 1095-1101.

Paunovič, S. A. \& Paunovič, A. S. (1995): Investigation of Apricot Germplasm Prunus armeniaca L. in situ in SFR Yugoslavia. Acta Hort., 384: 55-59, 384: 215-218.

Vachùn, Z. \& Krška, B. (1991): Metodika hodnocení pro výběr nejvhodnějších odrùd a hybridù, Lednice

Vachùn, Z., Krška, B., Sasková, H. \& Oboňová, J. (1996): The Breeding Programme and new Varieties of Apricots at Faculty Horticulture MUAF Brno at Lednice. Sci. Conf. Results of Using the gene Resources of Apricots and Peaches, $18^{\text {th }}-19^{\text {th }}$ July 1996, Bøeclav, Czech Republic, pp. 33-42.

Vachùn, Z., Krška, B., Sasková, H. \& Oboňová, J. (1995): Metodika hodnocení fenologických, pomologických a pěstitelských znakù (vlastností) meruňkových odrùd a hybridù, Lednice

Zhang-Li-Bin \& Liu-Guei (1997): Study on Correlations among quantitative traits in Siberian Apricot wild Seedlings and their Utilization. Journ. of Fruit Science, 14, 2: 121-123. 